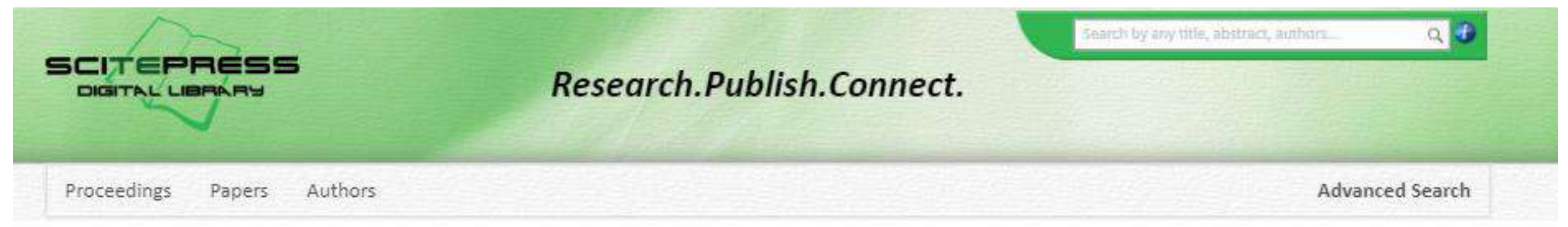

Search Results for: nafik

(1) 5 Select a Subject

Filter listed results, by

\section{> Publication date}

From: $2017 \mathbf{V}$ To: $2018 \quad$

\section{A Author}

Locate Author in list below

(a)

Add Author(s) to filter.

(1) Wisudanto (1)

[1] Elsha Sophia (1)

G. Imron Mawardi (1)

(1) imron Mawardi (1)

G Irham Zaki (1)

(]) M. Nafik Hadi Ryandhono (1)

(1) Muhammad Nafik Hadi Ryan. (1)

(1) Taqiyah Dinda Insani (1)

[ Tika Widiastuti (1)

(1) Tika Widiastuti \{1\}

1] 234
Papers (7) Authors (7)

Context (piease use complete words oniy)

Filter by selected fielil(s). Field

All fields

$\nabla$

Q

Sort by

Text Similarity

7

\section{Papers Found}

Linkage Model in Micro Sharia Financing for The Empowerment of MSME

Authors: Muhammad Nafik Hadi Ryandono, Tika Widiastuti and Imron Mawardi

Affiliation: Sharia Economics Department, Universitas Airiangga, H Airlangga No. 4, Surabaya and Indonesia, Indonesia

Digital Object Identifier: $10.5220 / 0007088607180723$

Proceedings of ICIEBP 2017, ISBN: 978-989-758-315-5

$\checkmark$ Quick Abstract

Islamic Social Entrepreneur Organization of Zakat Management in Empowerment of Socio-Economic Mustahiq in Indonesia

Authors: Tika Widiastuti ${ }^{-1}$, M. Nafik Hadi Ryandhono ${ }^{1}$, irham Zaki ${ }^{1}$, Imron Mawardi ${ }^{1}$, Wisudanto ${ }^{1}$ and Taqivah Dinda Insani ${ }^{2}$

Affiliations: ${ }^{1}$ Faculty of Economics and Business, Universitas Airlangga, Airlangga 4-6, Surabaya and Indonesia, Indonesia, ${ }^{2}$ Post Graduate School, Airlangga 4-6, Surabaya and indonesia, Indonesia

Digital Object Identifier: 10.5220/0007537600700075

Proceedings of ICPS 2018, ISBN: $978-989-758-348-3$ 


\section{Linkage Model in Micro Sharia Financing for The Empowerment of MSME}

In 1st intermational Conference on Islamic Economics, Busines5, and Philanthropy - Volume 1: 1CiEBP, 718-723, 2017, 8andung, Indonesia

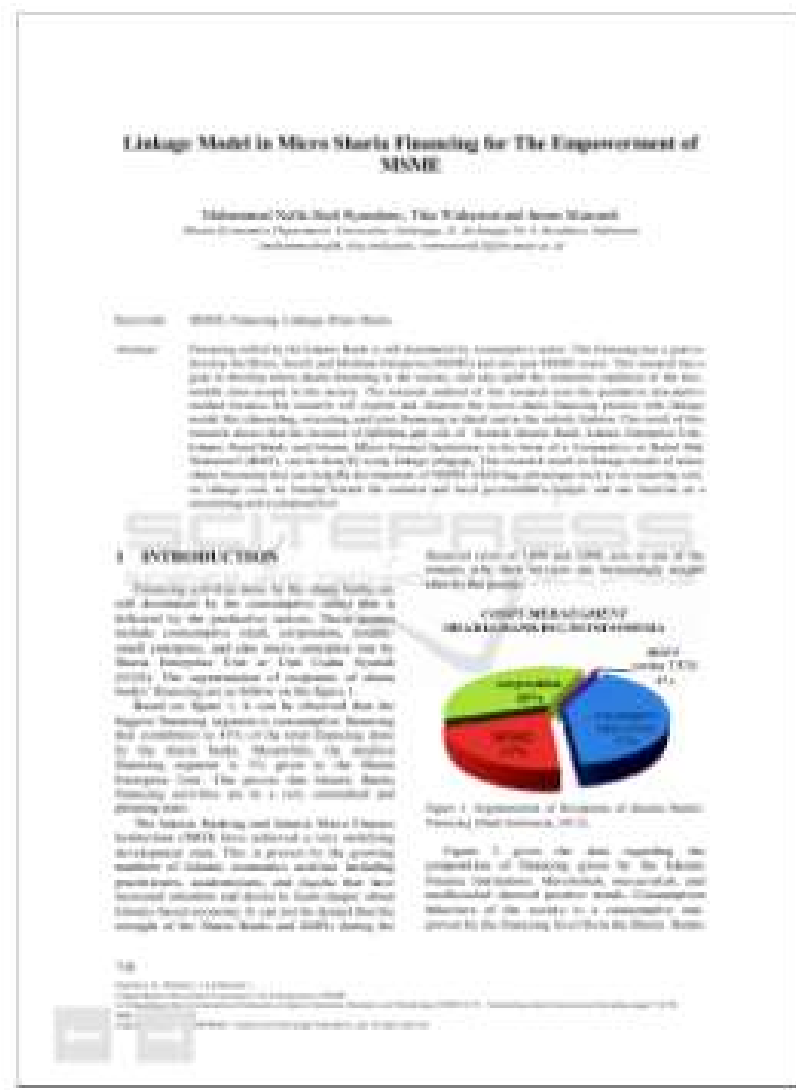

\section{Paper citation in several formats:}

Hanard Bibtex EndNote

Ryandono, M.; Widiastuti, T. and Mawardi, 1. \{2017\}, Linkage Model in Micro Sharia Financing for The Empowerment of MSME. In Ist intemotional Conference on isilomic Economics, Business, ond Philanthropy - Volume 1:10EBP, isBN 978-989-758315-5, pages 718-723. DOI: $10.5220 / 0007088607180723$

\section{Authors: Muhammad Nafik Hadi Ryandono ; Tika Widiastuti and imron Mawardi}

Affiliation: 5haria Economics Department, Universitas Airlangga, Jl. Airlangga No.4, Surabaya and Indonesia, indonesia

ISBNA: $978-989-758-315-5$

Keyword(s): MSME, Financing, Linkage, Micro Sharia.

Abstract: develop the Micro, Smail, and Medium Enterprise (MSME) and also non-MSME sector. This research has a goal to develop micro sharia financing in the society, and also uplift the economic condition of the low-middle class people in the society. The research method of this research uses the qualitative descriptive method because this research will explain and illustrate the micro sharia financing process with linkage mode/ like channeling, executing, and joint financing in detail and in the orderly fashion. The result of this research shows that the increase of function and role of General islamic Bank, islamic Enterprise Unit, Islamic Rural Bank, and islamic Micro Finance Institution, in the form of a Cooperative or Baitul Mal Wattamwil (BMT), can be done by using linkage program. This research result in linlage model of micro sharia financing that can help the development of MSME which has advantages such as no recurring cost, no linkage cost, no burden toward the national and local go (More)

\section{푤 Full Text c) $(1000$ CC BY-NC-ND 4 \\ Download \\ (1) Guest: Register as new SoTePress user now for free. \\ (6) Scitepress user: please login.}

You are not signed in, therefore limits apply to your IP address 36.81 .172 .170

Day Papers

In the current month:

Recent papers: 99 available of 100 total

Z' vears older papers: 200 available of 200 total 


\title{
Linkage Model in Micro Sharia Financing for The Empowerment of MSME
}

\author{
Muhammad Nafik Hadi Ryandono, Tika Widiastuti and Imron Mawardi \\ Sharia Economics Department, Universitas Airlangga, Jl. Airlangga No.4, Surabaya, Indonesia \\ \{muhammadnafik, tika.widiastuti, ronmawardi\}@feb.unair.ac.id
}

Keywords: $\quad$ MSME, Financing, Linkage, Micro Sharia.

Abstract: $\quad$ Financing rolled by the Islamic Bank is still dominated by consumptive sector. The financing has a goal to develop the Micro, Small, and Medium Enterprise (MSME) and also non-MSME sector. This research has a goal to develop micro sharia financing in the society, and also uplift the economic condition of the lowmiddle class people in the society. The research method of this research uses the qualitative descriptive method because this research will explain and illustrate the micro sharia financing process with linkage model like channeling, executing, and joint financing in detail and in the orderly fashion. The result of this research shows that the increase of function and role of General Islamic Bank, Islamic Enterprise Unit, Islamic Rural Bank, and Islamic Micro Finance Institution, in the form of a Cooperative or Baitul Mal Wattamwil (BMT), can be done by using linkage program. This research result in linkage model of micro sharia financing that can help the development of MSME which has advantages such as no recurring cost, no linkage cost, no burden toward the national and local government's budget, and can function as a monitoring and evaluation tool.

\section{INTRODUCTION}

Financing activities done by the sharia banks are still dominated by the consumptive sector that is followed by the productive sectors. Those sectors include consumptive retail, corporation, middlesmall enterprise, and also micro enterprise run by Sharia Enterprise Unit or Unit Usaha Syariah (UUS). The segmentation of recipients of sharia banks' financing are as follow on the figure 1 .

Based on figure 1, it can be observed that the biggest financing segment is consumptive financing that contributes to $41 \%$ of the total financing done by the sharia banks. Meanwhile, the smallest financing segment is $1 \%$ given to the Sharia Enterprise Unit. This proves that Islamic Banks financing activities are in a very committed and pleasing state.

The Islamic Banking and Islamic Micro Finance Institutions (IMFI) have achieved a very satisfying development state. This is proven by the growing numbers of Islamic economics activists including practitioners, academicians, and fuqaha that have increased attention and desire to learn deeper about Islamic-based economy. It can not be denied that the strength of the Sharia Banks and IMFIs during the financial crisis of 1998 and 2008, acts as one of the reasons why their services are increasingly sought after by the people.

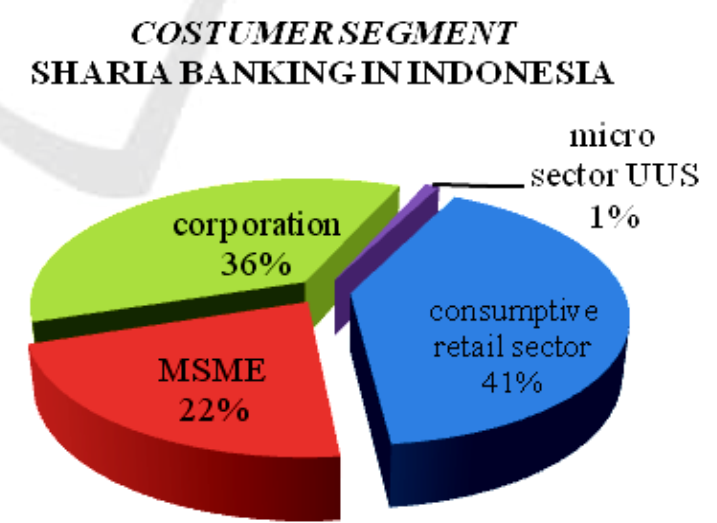

Figure 1: Segmentation of Recipients of Islamic Banks' Financing (Bank Indonesia, 2012).

Figure 2 gives the data regarding the composition of financing given by the Islamic Finance Institutions. Murabahah, musyarakah, and mudharabah showed positive trends. Consumption behaviors of the society is a consumptive one, proven by the financing level from the Sharia Banks 
in the murabahah skim, that dominate the highest financing amount with 505 trillion rupiah in the end of 2016. Financing in the productive sector, that can empower the real sector (micro, small, and medium enterprises), like mudharabah and musyarakah are having lower amount compared to the murabahah instead (Bintoro and Soekarto, 2013; Hunt-Ahmed, 2013; Oktafia, 2015; Rendra, 2015). Mudharabah financing with the smallest amount is in 2010 amounting to 8.6 trillion rupiah, while the smallest amount of musyarakah in 2010 have financing amount of 14.6 trillion rupiah.

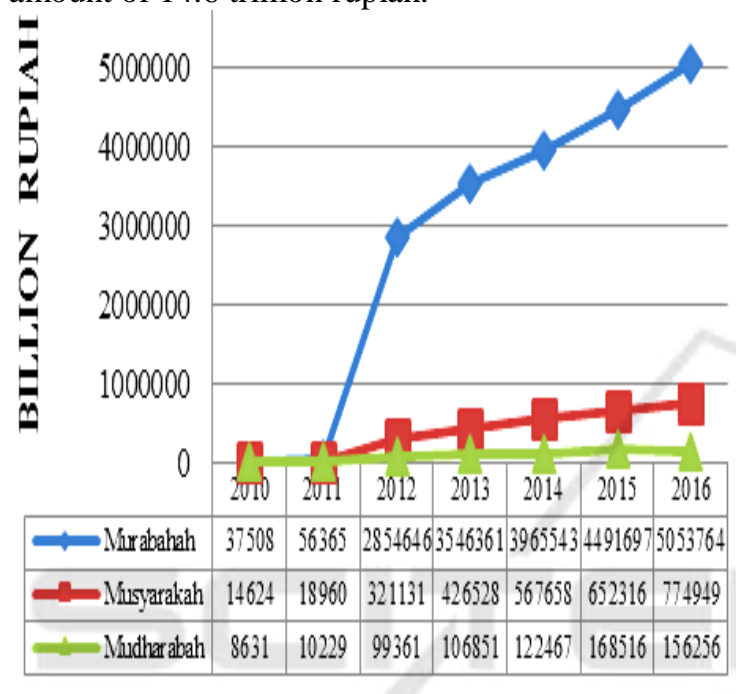

Figure 2: Composition of Financing from Islamic Finance Industry (Otoritas Jasa Keuangan, 2016).

External factors that can have effects on the success of micro banking business, especially Baitul Mal Wattamwil (BMT), including rational partners and customers that will ask for benefits and advantages in using the service of Islamic Financial Institution compared to the conventional banks, overlapping regulations, one of the example is regarding the supervision of Islamic Micro Financial Institution (IMFI) and Islamic Cooperative that needs further examination and rework, BMT has not been able to fulfill the demand of fund from the society, causing the economic growth of the lowerclass people to be hampered (Salam, Rahmania and Fauziyyah, 2014).

The linkage program scheme that is done by the banks and their partnering companies are divided into 3 types: channeling, executing, and joint financing (Arifin, 2013; Abdullah and Ismail, 2017). The difference of linkage program in Islamic Bank is the usage of a certain agreement ( $a k a d)$ in each of the schemes. Here is some of the formulated linkage program from various aspects of assessment:
Table 1: Assesment Aspects of Linkage Method (Bank Indonesia, 2012).

\begin{tabular}{|l|l|}
\hline $\begin{array}{c}\text { Assessment } \\
\text { Aspect }\end{array}$ & \multicolumn{1}{c|}{ Explanation } \\
\hline Segmet & $\begin{array}{l}\text { A low-class society that is unbankable } \\
\text { and unable to use the conventional } \\
\text { bank or General Islamic Bank, can be } \\
\text { made into the customer of linkage } \\
\text { banking, including MSMEs. }\end{array}$ \\
\hline Advantages & $\begin{array}{l}\text { The advantage of linkage banking } \\
\text { offered to the customers is the simple } \\
\text { payment scheme, no collaterals, and } \\
\text { also low-interest rate that can be } \\
\text { afforded by the poor and unbankable. }\end{array}$ \\
\hline Channel & $\begin{array}{l}\text { Channel used by the linkage banking } \\
\text { to reach their customer segment is } \\
\text { Business to Consumer (B2C) because } \\
\text { banking industry will need to come } \\
\text { directly to their customers. }\end{array}$ \\
\hline Partners & $\begin{array}{l}\text { Personal accompanying of the } \\
\text { customers, especially the MSMEs are } \\
\text { forms of the channel used by linkage } \\
\text { banking to reach their customers. }\end{array}$ \\
\hline Approach \\
Reurce
\end{tabular}




\begin{tabular}{|l|l|}
\hline \multirow{1}{*}{$\begin{array}{l}\text { Cost } \\
\text { Component }\end{array}$} & $\begin{array}{l}\text { they give. Also various communities } \\
\text { in the society that care about the } \\
\text { economic development in their } \\
\text { environment, and central and local } \\
\text { government. }\end{array}$ \\
$\begin{array}{l}\text { Cost components of linkage banking } \\
\text { consist of human resources that need } \\
\text { to have the ability to be on the field to } \\
\text { identify locations and numbers of poor } \\
\text { and unbankable people that need the } \\
\text { service of the bank, cost of opening } \\
\text { services, and other costs. The } \\
\text { advantage of linkage banking is the } \\
\text { reduction of high-costing information } \\
\text { regarding the customers, and also the } \\
\text { problems of law regarding credit } \\
\text { problems that increase the transaction } \\
\text { cost in the local credit market. The } \\
\text { positive sides of linkage banking are } \\
\text { the inclusion of many people toward } \\
\text { the service of banks including } \\
\text { segments of the society that were } \\
\text { previously unable to be serviced by } \\
\text { big commercial banks. }\end{array}$ \\
\hline
\end{tabular}

The assessment aspects of linkage banking as explained in table 1 mostly discussed the activity of linkage that often happened in the big banks or conventional banking industry, but for the assessment of Islamic Financial Institution, it is adapted to their operational principles that stem in the sharia values and norms.

There are several definitions of the empowerment concept (Sulistiyani, 2004), one of them is that explain that MSME consisted of 3 things, that is the creation of self-independence, business development, and growth of business potential. Basically, empowerment is the creation of condition or climate that give the MSME a chance to grow and develop. This logic is based on the assumption that there is no business type that can be done without any resources. MSME will face several challenges in this time and the coming time, primarily in these aspects (Tambunan, 2002), 1) Rapid technological advancement, There are many changes happening in the world of business caused by the advancement of technology and those can be viewed from two perspectives, the supply side and the demand side. Supply-side, means that technological advancement effect both the ways and methods of production, compositions, materials, and form and quality of a product. Meanwhile, the demand site causes the demand behavior to be changed, where at the beginning of the changes will be coming from the industry. If viewed from the perspectives of the demand of the society, after they are introduced to new technologies, then the consumer's demand will also change. So regarding this point, MSME is very much dependent on their flexibility level to adapts on many fronts in the face of technological advancements; 2) Open Competition, Business players, especially the MSME have to be able to take their opportunity to the open market to create more productively. Higher intensity, and also "tech-aware" have to be realized by the business players because technology will continue to advance faster every time and of course, it will be followed by the change of taste from the people. The increase in society's revenue will affect the rise of needs in the society, so every MSME and even big enterprise are challenged to adapt to these changes (Hamada, 2010).

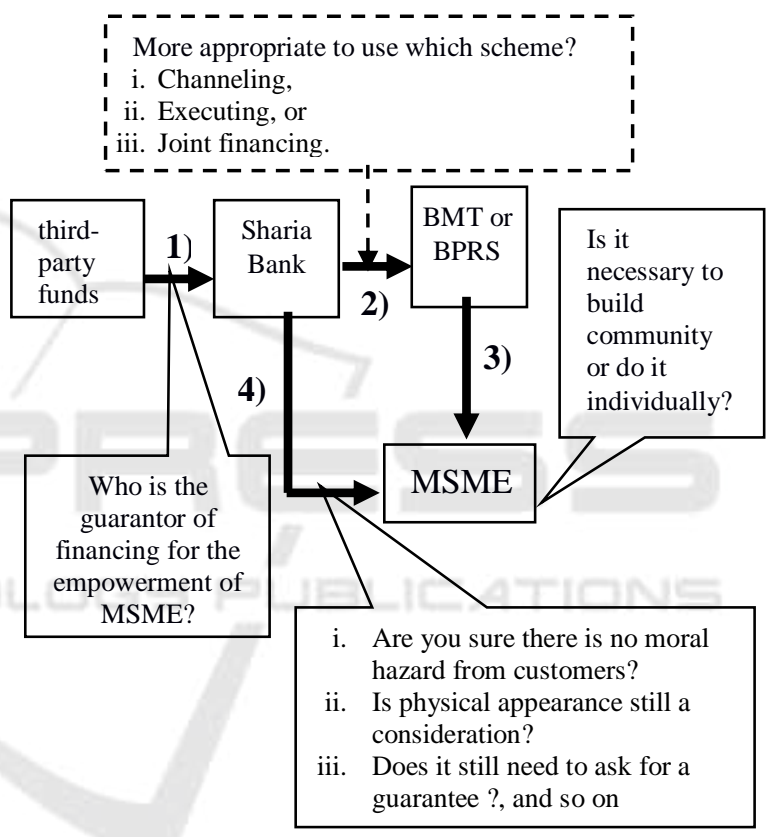

Figure 3: Conceptual Framework.

The solution of this research is explained in a way using the conceptual framework in figure 3 . In figure 3 , the grouping of problems is divided into 4 stages. First, starting from the workflow between the third-party fund giver to the Islamic Bank that discusses the question of "who will guarantee the financing of the MSMEs'. Second, the Islamic Bank will have to decide what scheme will be most appropriate if they want to involve BMT or Islamic Rural Bank in the channeling of the fund to the MSME. Third, BMT or Islamic Rural Bank will have to identify the profile of the MSMEs from the aspect of habits in doing business, whether or not the BMT create a community raise the effectiveness of the financing, or even it is sufficient to trust it to an 
individual. Fourth, Islamic Bank can channel the financing directly only with the joint financing scheme. So there is more detailed task for the Islamic Bank, that is to consider whether micro-level consumers with no high purchasing power, informal appearances, high potential to do moral hazard, and still ask for fixed assets as primary collateral are worth it.

Based on the background study regarding the theoretical study and empirical study of IMFI's and Islamic Banking's operational activities, then the problem formulation of this research will be "How the linkage model of financing in Micro-sharia Baitul Mall Wattamwil (BMT) will empower the Micro, Small, and Middle Enterprises in East Java?"

\section{METHODOLOGY}

The research approach used is qualitative descriptive research, because, this research will explain and figure the linkage model of micro sharia financing, like channeling, executing, and joint financing, in a detailed and orderly fashion. The chosen object of this research is Baitul Mal Wattamwil (BMT) located in East Java. BMT was chosen because the micro sharia financing in Indonesia, especially in East Java, are often practiced by IMFIs, including BMT. The sample choosing of this research uses purposive sampling technique. Type and source of data that will support this research are from primary and secondary data. The primary data is data gained directly from the informant, by using interview, documentation, and observation.

The emphasized in this research is the primary data, therefore the researcher decided that BMT employees that understand the workflow of financing requisition and channeling to the partners and customers of the BMT are the most appropriate to be used as the informants. Besides the BMT employees, there are several customers of that BMT that were also used for the informant of this research.

The data validation in the qualitative approach happens in the process of data collection, and to determine the validation of the data there needs to be a rechecking method. The application of the rechecking method is based on certain criteria and in the process of validating the data, then the researcher uses the triangulation method. The validation method (Sugiyono, 2010) is divided into 3 methods, first, source triangulation is a way to check the validity of the data by checking data from different sources. Second, method triangulation is a way of checking the credibility by checking the same source of data with different methods. Third, time triangulation is a way to test the originality and credibility of the data by considering the time when the research was done.

\section{RESULTS AND DISCUSSION}

The increase of the function and role of Islamic Bank can be done by doing linkage program between GIB, IEU, RIB, and IMFI. The relationship model between the parties in a linkage program can be seen in figure 4 . This program will be effective if Bank Indonesia and Indonesian government as the regulators for the Islamic Finance Institution can be directly involved. This linkage also involves consultants as the companion that can be from university or Bank's Partner Finance Consultant. The accompanying institution function to increase the capacity building for the LKMS, also function to minimalize the risk that may arise from the receiving partner of the linkage fund. The risk of channeling of the fund can be minimalized by involving the credit guaranteeing companies from the local area. Another method that can be used to minimize the risk is by using Tanggung Renteng system, it can be between the KSPPS, USPPS, or another member of financing recipients.

According to the explanation above, it can be seen that the existence of interest will make the goal of capital empowerment of MSME, which in the beginning is used to stimulate the economy, will not be effective. The profit-sharing system has various advantages compared to fixed interest system. Those advantages are : 1) No Recurring Cost , In a Profit Loss Sharing (PLS) system, there is no recurring cost that exists when we use interest rate system. Because the payment to the creditor is based on the revenue gained by the debtor. The profit-sharing payment is done based on the nisbah of mutual agreement when the akad or contract is agreed upon. The payment of profit-sharing is not considered a cost and have variable characteristic depending on the rate of revenue gained by the partners or the customers of linkage program. 


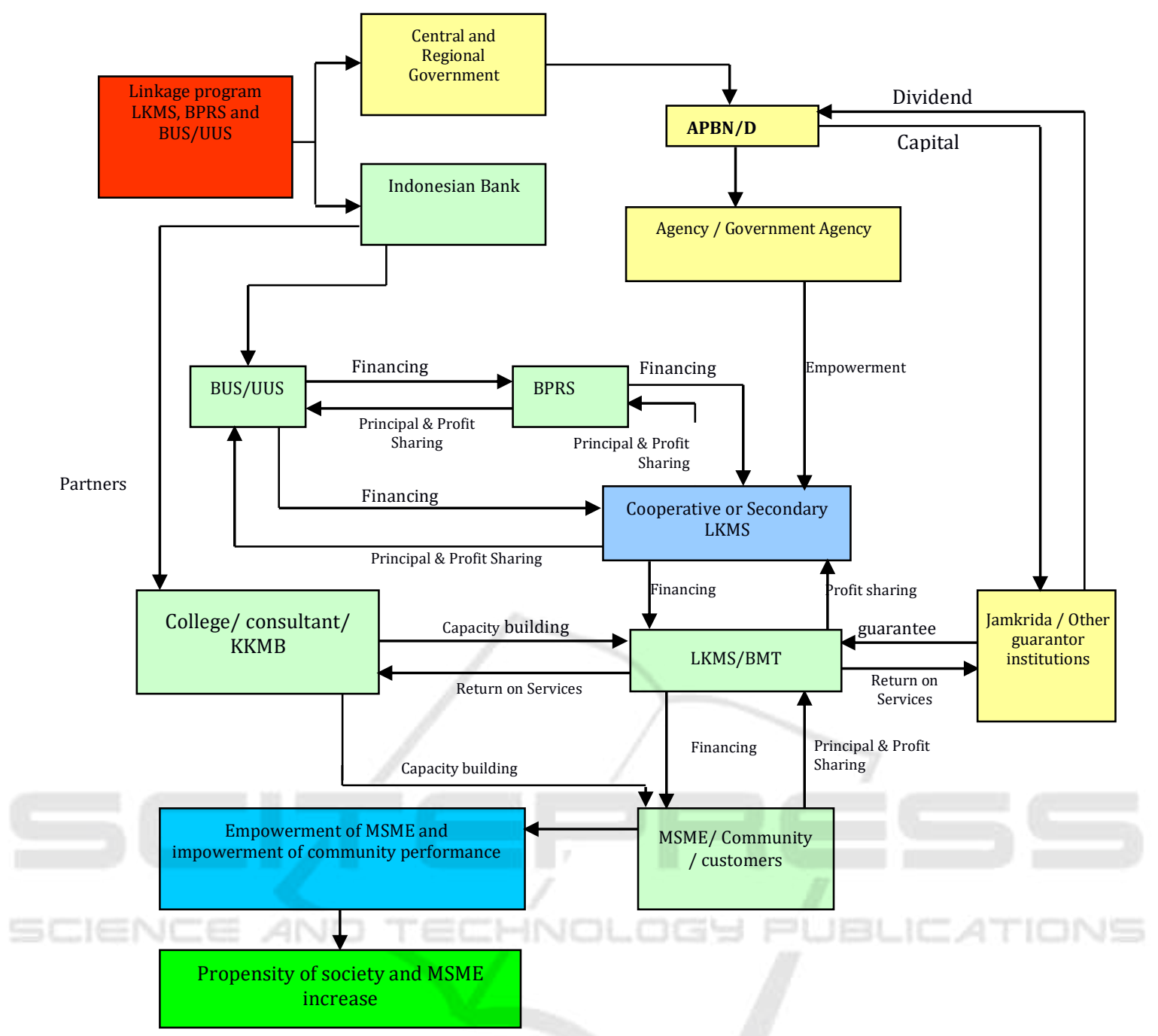

Figure 4: Linkage Model of GIB, IEU, RIB, and IMFI Model Linkage BUS, UUS, BPRS, and LKMS.

If the revenue increased, then the profit-sharing will be increased too. Otherwise, if the revenue comes down, then the profit-sharing will decrease too. If the partner does not receive their revenue or they are experiencing loss, then they will have no obligation to pay the profit-sharing. This way, there will be no need to sell assets or decrease the capital of their venture just to pay the profit-sharing, so the business process will be uninterrupted. In the other hand, if economic instability should happen, the partner will have an easier time to adapt because they will are not burdened by the recurring costs of interest rate.; 2) No linkage cost, Profit and Loss Sharing does not most the creation of efficient linkage and networking process, it even stimulate it. This condition can happen because of the PLS system. A financial institution who receive or do the partnership with other financial institutions will not "sell" their funds more expensively than their source of funds. The PLS system does not increase the cost or inefficiency even though the financing chain gets longer, so it will make them more accessible to the ordinary citizen and MSME which are the target demographic of this program; 3) Does not burden nation's and local's budgetary, Payment of profitsharing is an income-based system, not fund based system. Therefore, this system would not need the subsidy from the government because the government would not need to subsidize there curring interest payment borne by their recipient of linkage program's financing. The government can do their mission to empower the society through the MSME by strengthening their capital without the need to give subsidy for the payment of profitsharing paid by the MSME. Because there is no cost and subsidy, then the empowerment of MSE will be 
a burden to the government's budgetary; 4) Function as Monitoring and Evaluation tool, The profitsharing system will automatically function as a system of evaluating and monitoring the financing given to the partners. Payment of profit-sharing by the recipients of financing have to give the report of their business operation, including a financial report. The calculation of sharing-profit system will be done by using the financial report that was submitted by the partners, so they can determine the amount that the financial institution and MSME will receive.

\section{CONCLUSIONS}

The linkage model financing done by the BMT by involving external party has been known to the general population. The partnership scheme of the Islamic Bank with the external party, whether Islamic Rural Bank or Baitul Maal Wattamwil (BMT), are channeling, executing, and joint financing. This program will be effective if Bank Indonesia and the government as the regulator of Islamic Finance Institution. The existence of linkage program is seen as the solution for the MSME who needs capital and Islamic Bank who has excess liquidity. These linkage systems (mudharabah and musyarakah) have many benefits compared to the conventional system (interest), including no recurring cost, no linkage cost, does not burden the government'sbudgetary, functioning as monitoring and evaluating tool, every involved party have direct responsibility for the business, constant mentoring, accompanying, and development of the business, every fund will not be reduced but will increase instead so instead of burdening the government's budgetary it might help increase the government's revenue instead.

\section{REFERENCES}

Abdullah, R., Ismail, A. G., 2017. Taking stock of the waqf-based Islamic microfinance model. International Journal of Social Economics. Emerald Publishing Limited, 44(8), pp. 1018-1031.

Arifin, J., 2013. Hubungan Hukum Kemitraan Dalam Linkage Program Perbankan Syari'ah. Economica: Jurnal Ekonomi Islam. 4(2), pp. 43-54.

Bank Indonesia, 2012. Kajian Model Bisnis Perbankan Syariah, Direktorat Perbankan Syariah, BI. Jakarta.

Bintoro, M. H., Soekarto, S. T., 2013. Strategi pengembangan koperasi jasa keuangan syariah dalam pembiayaan usaha mikro di Kecamatan Tanjungsari, Sumedang. MANAJEMEN IKM: Jurnal Manajemen
Pengembangan Industri Kecil Menengah. 8(1), pp. 27-35.

Hamada, M., 2010 Commercialization of microfinance in Indonesia: the shortage of funds and the linkage program. The Developing Economies. Wiley Online Library, 48(1), pp. 156-176.

Hunt-Ahmed, K., 2013. How Does an Islamic Microfinance Model Play the Key Role in Poverty Alleviation?: The European Perspective. Contemporary Islamic Finance: Innovations, Applications, and Best Practices. John Wiley \& Sons, Inc., pp. 245-253.

Oktafia, F., 2015. Analisis pembiayaan linkage koperasi dengan prinsip mudharabah: Studi pada Bank BRI Syariah Cabang Malang, Universitas Islam Negeri Maulana Malik Ibrahim.

Otoritas Jasa Keuangan, 2016. Statistik Perbankan Syariah, Jakarta.

Rendra, B., 2015. Dampak Pembiayaan Sektor Pertanian Oleh LembagaPembiayaan Syariah Terhadap Tingkat Kesejahteraan Para Petani (Studi Kasus Kecamata Torjun, Kabupaten Sampang). JAB. 12(1).

Salam, A. N., Rahmania, H. P., Fauziyyah, N. E., 2014. Model Optimalisasi Lembaga Keuangan Mikro Syari'ah (Lkms) Dalam Rangka Pengembangan Dan Pemberdayaan Wilayah Pedesaan. Kumpulan Hasil Riset Terbaik, Forum Riset Keuangan Syariah, Institut Pertanian Bogor.

Sugiyono, P. D., 2010. Metode penelitian pendidikan, Pendekatan Kuantitatif, Alfabeta. Bandung.

Sulistiyani, A. T., 2004. Kemitraan dan model-model pemberdayaan, Graha Ilmu. Yogyakarta.

Tambunan, T., 2002. Usaha Kecil dan Menengah di Indonesia: Beberapa Isu Penting, Salemba Empat. Jakarta. 